\title{
Article \\ Competitiveness of the EU Agri-Food Sector on the US Market: Worth Reviving Transatlantic Trade?
}

\author{
Karolina Pawlak (D)
}

check for updates

Citation: Pawlak, K. Competitiveness of the EU Agri-Food Sector on the US Market: Worth Reviving

Transatlantic Trade? Agriculture 2022, 12, 23. https://doi.org/10.3390/ agriculture12010023

Academic Editor: Giuseppe Timpanaro

Received: 3 December 2021

Accepted: 23 December 2021

Published: 26 December 2021

Publisher's Note: MDPI stays neutral with regard to jurisdictional claims in published maps and institutional affiliations.

Copyright: (C) 2021 by the author. Licensee MDPI, Basel, Switzerland. This article is an open access article distributed under the terms and conditions of the Creative Commons Attribution (CC BY) license (https:// creativecommons.org/licenses/by/ $4.0 /)$.
Department of Economics and Economic Policy in Agribusiness, Faculty of Economics, Poznan University of Life Sciences, Wojska Polskiego 28, 60-637 Poznan, Poland; karolina.pawlak@up.poznan.pl

\begin{abstract}
The systematically strengthening role of emerging economies has become a factor strongly determining the overall trade policy of the European Union (EU) and the United States of America (USA), as well as their bilateral relations. One of the initiatives aiming at the strengthening of economic ties within the transatlantic partnership, as a consequence promoting stabilization of the positions of the EU and the USA in the world economy, was related with negotiations concerning the Transatlantic Trade and Investment Partnership. The EU-USA trade talks were suspended at the end of 2016; however, the establishment of the EU-USA free trade area might be a breakthrough in the transatlantic relations, while the conclusion of this agreement would significantly determine the competitive position of the agri-food sector of these two economies, both in their bilateral relations and in world trade. In view of the above, the aim of this paper is to estimate the competitive position of the EU agri-food sector in transatlantic trade considering the conclusion of the agreement establishing the EU-USA free trade area. For this purpose, Widodo's method of mapping products on the target market was applied. Results from the conducted analyses suggest that from 2010-2020 comparative advantages gained by the EU on the US market were sources of an advantageous export specialization. In view of the forecasted dynamic increase in agri-food export from the EU to the USA caused by possible liberalization of bilateral trade, the relatively strong competitive position of the EU on the American market might be maintained or even strengthened. However, such a situation would be determined by the regulatory cooperation progressing with the reduction of tariffs.
\end{abstract}

Keywords: international competitive position; comparative advantage; agri-food products; transatlantic trade; transatlantic partnership; products' mapping

\section{Introduction}

Along with the processes of economic development, industrialization and servitization of economies we may observe a trend towards a reduction in the share of raw materials and agricultural products in world exports. Nevertheless, in view of the spatial distribution of production dependent on natural and climatic conditions, the exchange of agri-food products between individual countries and regions of the world remains an important and indispensable part of global trade. For decades, countries of Europe and both Americas have been the largest participants in international agricultural trade. In 1937, the European countries accounted for approximately $66 \%$ world imports and almost $35 \%$ exports of agri-food products, while countries of North and Latin America supplied the world market with about $30 \%$ total exports of agri-food products and absorbed $20 \%$ of imports [1]. In 2020, European countries executed roughly $43 \%$ of global exports and $41 \%$ of imports, while countries in both Americas accounted for $27 \%$ exports and $18 \%$ imports [2]. This means that in the period of 1937-2020, European countries gained in importance as food exporters, at the same time reducing the degree of import penetration in this segment of the market, whereas countries in the Americas maintained their stable position in the world agri-food market.

Starting from the 1970s, economically developed countries have been expanding their trade. Goods produced in industrialized countries, primarily thanks to the greater export 
potential of these countries, a greater range of goods to be exchanged as well as stronger mutual economic ties and integration efforts, have proven to be more competitive on international markets [3]. Such a trend has also been manifested in agri-food trade, in which in the successive decades of the 20th and 21st centuries a process of trade concentration has been observed in more economically developed countries.

The greatest world exporters of agri-food products include the European Union (EU) 27 countries (the EU without the UK) and the United States of America (USA). Depending on whether this calculation includes intra-EU exchange or not, the EU countries in 2020 generated $36 \%$ (in terms of the total EU trade, i.e., total intra-EU trade and trade with third countries) or 13\% (excluding the intra-EU trade), while the USA accounted for $9 \%$ of global exports [2]. In view of the dominant role of the intraregional trade in the EU, the transatlantic relations may be considered in terms of both cooperation and competition. In the 21st century they face a crisis weakening the geostrategic position of the EU and the USA, as well as the increasing competitive pressure on the part of emerging economies, such as Brazil, Russia, India, China and South Africa (BRICS).

The systematically strengthening role of the BRICS countries has become a factor strongly determining the overall trade policy of the EU and the USA, as well as their bilateral relations. The position of the EU and the USA in international agricultural trade is manifested not only in the considerable share in world trade, but also in their negotiation standing in the World Trade Organization (WTO) as well as the simultaneous, active initiation or strengthening of trade relations within preferential trade agreements. In view of the inability to conclude an agreement on liberalization of world trade, both the EU and the USA started to change the model of the implemented trade policy and prioritize regional liberalization of trade, which was reflected in numerous bilateral trade agreements signed by these countries. One of the initiatives aiming at the strengthening of economic ties within the transatlantic partnership, as a consequence promoting stabilization of the positions of the EU and the USA in the world economy, was related with negotiations concerning the Transatlantic Trade and Investment Partnership (TTIP), initiated in June 2013.

The primary aim of the TTIP was connected with the liberalization of broadly understood economic exchange between the EU and the USA, which, thanks to the lifting of tariff and non-tariff restrictions in the access to the market of both partners, boosted mutual trade and investments, while, thanks to the initiated multiplier effect, might contribute to the acceleration of economic growth. Negotiations focused on three areas, covering access to the market, regulatory cooperation and non-tariff barriers to trade, as well as the principles and methods of cooperation in order to provide joint solutions of global problems. In terms of access to the market it was intended to eventually completely eliminate tariffs in trade in industrial and agricultural goods. It was also planned to reduce non-tariff barriers as well as simplify and develop common regulations concerning the rules of origin of goods [4-6]. Similarly, as within the WTO, the agricultural sector was one of the most difficult and disputable areas of TTIP negotiations. On the one hand, this resulted from the considerable scale of protectionism and political sensitivity of this sector, which both in the USA and in many EU countries, was manifested in the activity of a strong lobby promoting solutions in the trade policy advantageous for operators in the agricultural sector. On the other hand, a stalemate in the negotiations was connected with significant differences in the sanitary and phytosanitary regulations, testing requirements, inspections and certification, as well as protected designations of origin and protected geographical indications [7].

Due to the increasing anti-American sentiments and a wave of public protests in Europe caused, e.g., by a lack of transparency of these negotiations and the low level of information on the TTIP negotiations and the content of the TTIP agreement among the general public, as well as increasing protectionist trends in the United States (US) trade policy [8-10], TTIP negotiations were suspended at the end of 2016. It may be assumed that when striving to minimize losses resulting from American protectionism, the EU will attempt to resume negotiations towards a bilateral agreement on the elimination of trade barriers in its trade with the USA. If the will to conclude this agreement is also evident on 
the part of the USA, the scope may be narrower and the provisions less ambitious than it had been initially assumed in the TTIP negotiations. However, it seems that such a solution might both overcome resistance of the previously reluctant EU member countries, as well as promote a consensus in these negotiations. The establishment of the EU-USA free trade area would be a breakthrough in the transatlantic relations, while the conclusion of this agreement would significantly determine the competitive position of the agri-food sector of these two economies both in their bilateral relations and in world trade.

In view of the above the aim of this paper is to estimate the competitive position of the EU agri-food sector in transatlantic trade considering the conclusion of the agreement establishing the EU-USA free trade area. This study may constitute the basis for the evaluation of changes in comparative advantages in the case of the conclusion of an agreement establishing an EU-USA free trade area and determination whether it would offer a chance for the development of bilateral relations consistent with the obtained comparative advantages, or rather pose a risk of weakening the competitive position of the EU agri-food sector on the US market.

\section{Literature Review}

2.1. Possible Economic Effects of the Transatlantic Trade and Investment Partnership for the EU and US Economies

Establishment of the free trade area between the EU and the USA within the framework of the Transatlantic Trade and Investment Partnership (TTIP) was a key element in transatlantic relations in the 21st century. Initiation of negotiations concerning the TTIP was a manifestation of political will to bind more closely the EU and US economies as a result of attempts to search for new methods to accelerate economic growth and face competitive pressure from the emerging superpowers. Expected benefits stemming from the liberalization of bilateral trade constituted a strong impulse to undertake negotiations, which were facing several threats. Firstly, even before the talks were started the parties of the future partnership failed to agree on the scope of the negotiations and the USA, which expected comprehensive negotiations on all subjects with no exceptions, did not want to accept the intention of the EU to exclude from the negotiations issues of the cultural policy and some aspects of the agricultural policy. Secondly, discrepancies between the partners concerning the applied non-tariff measures were so significant that any attempt towards a cohesion of the regulatory systems binding on both sides of the Atlantic would face serious problems. This was particularly evident in the case of the agri-food sector. Additionally, there were very few instances of previous cooperation in this respect, which would have brought tangible results. Thirdly, in view of the differing distribution of expected benefits and losses resulting from the conclusion of the agreement between individual EU countries and sectors of the economies of both partners, support of specific interest groups and political fractions for the negotiated agreement varied and changed in time. Fourthly, time was a factor undermining chances for the successful conclusion of the negotiations. A difficult economic situation in the Euro zone in the initial period of the negotiations was an additional element persuading the parties to conclude this difficult, but ambitious agreement. In view of the systematically weakening position of the EU and the USA in the world economy, the relative scale of benefits generated by the establishment of the transatlantic free trade area was decreasing, and thus limiting the will to establish this partnership [11].

The final version of the free trade agreement between the EU and the USA would obviously be influenced by the scale of estimated macro- and meso-economic benefits. It results from simulation analyses conducted to date that the elimination of tariffs and reduction of non-tariff barriers to bilateral trade in goods and services would contribute to gross domestic product (GDP) growth in both economies, with the estimated changes in gross domestic product in the EU countries potentially being greater than in the USA (Table 1). At the complete elimination of tariffs and a reduction of non-tariff barriers to the mutual trade of the EU with the USA by $25 \%$, GDP in the USA might increase by $0.4 \%$ 
and in the EU by $0.5 \%$ [12-14]. Only [15] at the same scale of liberalization indicated a comparable $0.3 \%$ growth in GDP in both economies. According to [16], a similar effect for the USA could also be provided by the limitation of non-tariff barriers by $50 \%$ (without any interference into tariffs), whereas in the EU such a liberalization scenario might bring about an increase in GDP by $0.72 \%$. Elimination of non-tariff measures turns out to be crucial for the expected wealth effects of the TTIP for both trade partners. Assuming the $50 \%$ reduction of non-tariff barriers accompanying the complete elimination of tariffs in the EU trade with the USA, GDP growth could amount to $0.9 \%$ in the USA and $1.2 \%$ in the EU [17], i.e., by approximately 0.5 and 0.7 percentage points more than in the case of non-tariff measures being lowered by half.

Table 1. Estimated macroeconomic impacts of the TTIP on the EU and the US economies (changes in $\%$ compared to status quo).

\begin{tabular}{|c|c|c|c|c|c|c|c|c|c|c|}
\hline \multirow[b]{2}{*}{ Author } & \multicolumn{2}{|c|}{ Scenario Assumptions } & \multicolumn{8}{|c|}{ Estimated Changes (\%) } \\
\hline & $\begin{array}{c}\text { Tariff } \\
\text { Cut }(\%)\end{array}$ & $\begin{array}{l}\text { Reduction of } \\
\text { Non-Tariff Barriers } \\
\text { to Trade in Goods } \\
\text { and Services (\%) }\end{array}$ & $\begin{array}{l}\text { GDP in } \\
\text { the EU }\end{array}$ & $\begin{array}{l}\text { GDP in } \\
\text { the US }\end{array}$ & $\begin{array}{l}\text { Export } \\
\text { from the } \\
\text { EU to the } \\
\text { US }\end{array}$ & $\begin{array}{l}\text { Export } \\
\text { from the } \\
\text { US to the } \\
\text { EU }\end{array}$ & $\begin{array}{l}\text { Export } \\
\text { from the } \\
\text { EU in } \\
\text { Total }\end{array}$ & $\begin{array}{l}\text { Export } \\
\text { from the } \\
\text { US in } \\
\text { Total }\end{array}$ & $\begin{array}{l}\text { Import to } \\
\text { the EU in } \\
\text { Total }\end{array}$ & $\begin{array}{l}\text { Import to } \\
\text { the US in } \\
\text { Total }\end{array}$ \\
\hline $\begin{array}{l}\text { Berden } \\
\text { et al. [16] }\end{array}$ & $\begin{array}{c}\text { not } \\
\text { assumed }\end{array}$ & 50 & $\begin{array}{c}+0.72 \\
\text { per year }\end{array}$ & $\begin{array}{l}+0.28 \\
\text { per year }\end{array}$ & ne & ne & +2.07 & +6.06 & +2.00 & +3.93 \\
\hline $\begin{array}{l}\text { Fontagné, } \\
\text { Gourdon, } \\
\text { Jean [15] }\end{array}$ & 100 & 25 & +0.3 & +0.3 & +49.0 & +52.5 & $\begin{array}{l}+2.3^{\mathrm{a}} / \\
+7.6^{\mathrm{b}}\end{array}$ & +10.1 & $\begin{array}{l}+2.2^{\mathrm{a}} / \\
+7.4^{\mathrm{b}}\end{array}$ & +7.5 \\
\hline $\begin{array}{l}\text { Francois } \\
\text { et al. [12] }\end{array}$ & $\begin{array}{c}98 \\
100\end{array}$ & $\begin{array}{l}10 \\
25\end{array}$ & $\begin{array}{l}+0.27 \\
+0.48\end{array}$ & $\begin{array}{l}+0.21 \\
+0.39\end{array}$ & $\begin{array}{l}+16.16 \\
+28.03\end{array}$ & $\begin{array}{l}+23.20 \\
+36.57\end{array}$ & $\begin{array}{l}+3.37^{\mathrm{b}} \\
+5.91^{\mathrm{b}}\end{array}$ & $\begin{array}{l}+4.75 \\
+8.02\end{array}$ & $\begin{array}{l}+2.91^{\mathrm{b}} \\
+5.11^{\mathrm{b}}\end{array}$ & $\begin{array}{l}+2.81 \\
+4.74\end{array}$ \\
\hline $\begin{array}{c}\text { European } \\
\text { Commission } \\
{[13]}\end{array}$ & 100 & $25^{c}$ & +0.51 & +0.38 & +26.95 & +35.73 & $+8.16^{\mathrm{b}}$ & +11.43 & $+7.39^{b}$ & +4.59 \\
\hline WTI [14] & 100 & 25 & $\begin{array}{c}+0.5 \\
\text { per year }\end{array}$ & $\begin{array}{c}+0.4 \\
\text { per year }\end{array}$ & +28.0 & +37.0 & +6.0 & +8.0 & ne & ne \\
\hline $\begin{array}{c}\text { Rojas- } \\
\text { Romagosa } \\
{[17]}\end{array}$ & 100 & 50 & +1.2 & +0.9 & +111.4 & +119.0 & +6.3 & +21.4 & +9.0 & +23.8 \\
\hline
\end{tabular}

Note: ${ }^{\mathrm{a}}$ — trade within the Single European Market and with third countries; ${ }^{\mathrm{b}}$ — trade with third countries only c_excluding non-tariff barriers to agri-food trade; ne-not estimated. Source: [12-17], the author's elaboration.

Similar conclusions may be provided by the analysis of potential trade effects of the establishment of the EU-USA free trade area. Francois et al. [12], the European Commission [13] and the World Trade Institute [14] predict that a complete elimination of tariffs and a reduction of non-tariff barriers by $25 \%$ could result in exports from the USA to the EU increasing by approximately $37 \%$, while exports from the EU to the USA would increase by $28 \%$. In turn, increasing the level of reduction in non-tariff measures to $50 \%$ might lead to an increase in bilateral exports by $119 \%$ and $111 \%$, respectively [17]. Assuming the same liberalization scenario, an even higher growth of about $50 \%$ was forecasted for bilateral transatlantic trade [15]. It may be assumed that the volume of estimated trade effects is dependent on the initial level of tariff equivalents of non-tariff barriers adopted in individual analyses, as well as the level of (dis)aggregation of conducted studies.

It results from conducted simulations that the USA could gain greater benefits from the development of mutual trade, while at present this country has to overcome a higher level of protection of the EU market than the one protecting the American market against exporters from the EU. This is consistent with integration theory, according to which the higher the level of trade barriers applied prior to the establishment of the preferential trade area, the greater the power of the trade creation effect manifested after its establishment. The trade creation effect may be manifested to a lesser extent in the total volume of trade of the EU and the USA. Depending on the scope and scale of planned liberalization of transatlantic trade we may expect an increase in total exports from the EU ranging from $2 \%$ to $6 \%$, while for imports from $2 \%$ to $9 \%$, and an increase in the exports from the USA ranging from $5 \%$ to $21 \%$ and imports increasing from $4 \%$ up to $24 \%$ (Table 1 ). The impact of an increase in bilateral trade on the total trade volumes in the analyzed economies results from the importance of the trade partner granted preferential access to the market 
in the total trade volume of a given country. Moreover, in this case, we may observe an asymmetry of benefits from the increase in trade to the advantage of the USA.

\subsection{Possible Agri-Food Effects of the Transatlantic Trade and Investment Partnership}

The political will and decisions at the national level required to execute enterprises at the transnational level may be determined by the sector approach $[18,19]$. For this reason, the future transatlantic relations and the scope of cooperation of the EU with the USA in the pre-arranged areas will be influenced by the expected effects of the planned agreement at the mesoeconomic level, particularly concerning the sensitive sectors. The agri-food sector may serve as an example in this respect.

Results of simulation analyses published to date on the effects of the Transatlantic Trade and Investment Partnership (TTIP) implementation for the EU countries and the USA indicate that in both cases the dynamics of the increase in bilateral agricultural trade may be higher than that of total trade-the greater the scope of planned liberalization, the larger it would be (Table 2). For example, according to [20], already a partial liberalization of trade, consisting solely in the elimination of import tariffs in mutual trade relations of the EU and the USA, while disregarding consequences of the potential reduction of non-tariff barriers, might cause a $18.5 \%$ increase in exports of agri-food products from the EU to the USA and an almost 31\% increase in imports from the USA to the EU. More comprehensive liberalization scenarios, assuming not only the removal of tariffs, but also a more or less ambitious reduction of non-tariff barriers to trade in goods and services (a 10\% or 25\% reduction of the ad valorem equivalents of non-tariff barriers) predict an even greater effect of agri-food trade creation. Simultaneous elimination of tariffs and limitations on the use of non-tariff measures might lead to increased exports of agri-food products from the EU to the USA by almost $56.5 \%$ and an increase in imports of agri-food products from the American market to the EU by over 116\% [20]. As in the case of total trade, in view of the asymmetry in the level of market protection a stronger impulse for the increase in exports would be manifested in the USA rather than the EU. In turn, due to the relatively small role of bilateral trade between the EU countries and the USA in the total trade volume most probably no significant changes would be observed in the total agri-food trade of the analyzed countries.

Table 2. Estimated impacts of the TTIP on the EU and the US agri-food sectors (changes in \% compared to status quo).

\begin{tabular}{|c|c|c|c|c|c|c|c|c|c|c|c|c|c|c|}
\hline \multirow{3}{*}{ Author } & \multicolumn{2}{|r|}{ Scenario Assumptions } & \multicolumn{12}{|c|}{ Estimated Changes (\%) } \\
\hline & \multirow{2}{*}{$\begin{array}{l}\text { Tariff } \\
\text { Cut } \\
(\%)\end{array}$} & \multirow{2}{*}{$\begin{array}{l}\text { Reduction of Non-Tariff } \\
\text { Barriers to Trade in } \\
\text { Goods and Services (\%) }\end{array}$} & \multicolumn{2}{|c|}{$\begin{array}{l}\text { Export from } \\
\text { the EU to } \\
\text { the US }\end{array}$} & \multicolumn{2}{|c|}{$\begin{array}{l}\text { Import from } \\
\text { the US to } \\
\text { the EU }\end{array}$} & \multicolumn{2}{|c|}{$\begin{array}{l}\text { Export from the } \\
\text { EU to Third } \\
\text { Countries }\end{array}$} & \multicolumn{2}{|c|}{$\begin{array}{l}\text { Export from } \\
\text { the US in } \\
\text { Total }\end{array}$} & \multicolumn{2}{|c|}{$\begin{array}{l}\text { Import to the } \\
\text { EU From Third } \\
\text { Countries }\end{array}$} & \multicolumn{2}{|c|}{$\begin{array}{l}\text { Import to the } \\
\text { US in Total }\end{array}$} \\
\hline & & & A & B & A & B & A & B & A & B & A & B & $\mathbf{A}$ & B \\
\hline $\begin{array}{l}\text { Fontagné, } \\
\text { Gourdon, } \\
\text { Jean [15] }\end{array}$ & 100 & 25 & +149.5 & ne & +168.5 & ne & +7.0 & ne & +12.6 & ne & -1.5 & ne & -0.8 & ne \\
\hline $\begin{array}{l}\text { Francois } \\
\text { et al. [12] }\end{array}$ & $\begin{array}{c}98 \\
100 \\
\end{array}$ & $\begin{array}{l}10 \\
25\end{array}$ & $\begin{array}{l}+16.3 \\
+15.1 \\
\end{array}$ & $\begin{array}{l}+26.1 \\
+45.5 \\
\end{array}$ & $\begin{array}{l}+20.5 \\
+21.8 \\
\end{array}$ & $\begin{array}{l}+56.5 \\
+74.8 \\
\end{array}$ & $\begin{array}{l}+0.41 \\
+0.22 \\
\end{array}$ & $\begin{array}{l}+5.21 \\
+9.36 \\
\end{array}$ & $\begin{array}{l}+0.67 \\
+1.07 \\
\end{array}$ & $\begin{array}{l}+4.58 \\
+6.85 \\
\end{array}$ & $\begin{array}{l}+3.84 \\
+5.22 \\
\end{array}$ & $\begin{array}{l}+6.26 \\
+10.07 \\
\end{array}$ & $\begin{array}{l}+1.18 \\
+0.59 \\
\end{array}$ & $\begin{array}{l}+9.15 \\
+16.37 \\
\end{array}$ \\
\hline $\begin{array}{c}\text { Bureau } \\
\text { et al. [20] }\end{array}$ & $\begin{array}{l}100 \\
100\end{array}$ & $\begin{array}{c}0 \\
25\end{array}$ & \multicolumn{2}{|c|}{$\begin{array}{l}+18.5 \\
+56.4\end{array}$} & \multicolumn{2}{|c|}{$\begin{array}{c}+30.7 \\
+116.3\end{array}$} & \multicolumn{2}{|c|}{$\begin{array}{c}-0.1 \\
0.0\end{array}$} & \multicolumn{2}{|c|}{$\begin{array}{l}-0.5 \\
-1.5\end{array}$} & \multicolumn{2}{|c|}{$\begin{array}{l}-0.4 \\
-1.5\end{array}$} & \multicolumn{2}{|c|}{$\begin{array}{l}-0.6 \\
-1.7\end{array}$} \\
\hline $\begin{array}{l}\text { Poczta- } \\
\text { Wajda, } \\
\text { Sapa [21] }\end{array}$ & 100 & 0 & \multicolumn{2}{|c|}{+8.5} & \multicolumn{2}{|c|}{+9.2} & \multicolumn{2}{|c|}{+0.78} & \multicolumn{2}{|c|}{ ne } & \multicolumn{2}{|c|}{+0.61} & \multicolumn{2}{|c|}{ ne } \\
\hline
\end{tabular}

Note: A-agricultural products; B-food products; ${ }^{c}$ - changes in trade refer to the total trade in agri-food products; ne-not estimated. Source: $[12,15,20,21]$, the author's elaboration.

Greater benefits from liberalization of transatlantic trade would be gained by exporters of food products rather than agricultural goods [12]. While, regardless of the scale of liberalization in non-tariff barriers to trade in goods and services, an increase in exports of agricultural products from the EU to the USA amounting to 15-16\% might be observed, in the case of food products a reduction of non-tariff barriers by $10 \%$ or $25 \%$, respectively, might lead to an increase of their exports by approximately $26 \%$ or $45.5 \%$. At the same 
time, we could expect an increase in the imports of agricultural products from the USA by $21-22 \%$ as well as an increase in purchases of processed food on the American market by $56.5 \%$ or $74.8 \%$ (adequately to the degree of liberalization in non-tariff measures) [12]. More dynamic changes in bilateral trade in agricultural products are forecasted by [15], who showed that the conclusion of the transatlantic agreement stipulating a complete elimination of tariffs and a $25 \%$ reduction of non-tariff measures might cause about a $150 \%$ increase in exports of agricultural products from the EU to the USA and an increase in their imports from the USA to the EU by 20 percentage points (p.p.) greater than in export. As far as the exchange with the other trade partners is concerned, a slight limitation of imports of agricultural raw materials and an increase in their exports from the EU and USA by 7\% and $12.6 \%$, respectively, could be recorded. Development of bilateral trade would thus be manifested less than proportionally in the trade relations of the analyzed countries with the other partners.

Markets most vulnerable due to changes resulting from the conclusion of the TTIP may be those of meat, milk, sugar, and cereals, as well as fruits and vegetables. It results from the simulation conducted by [20] that implementation of the TTIP might result in the EU-USA relations an over 4-fold increase in exports of red meat, an almost 3-fold increase in exports of poultry meat and sugar, an almost 2.5 -fold increase in revenue from exports of dairy products, an almost $170 \%$ increase in exports of cereals as well as a $90 \%$ increase in exports of fruit and vegetables. In turn, imports of the above-mentioned groups of products from the USA might grow 3.5-fold (red meat), 10-fold (poultry meat), 6-fold (sugar), 20-fold (dairy products) and slightly over 120\% (cereals) and a little below $97 \%$ (fruit and vegetables).

In previous negotiations on the transatlantic partnership, similarly as in the negotiations concerning establishment of many other preferential trade areas and those on the WTO forum, the agricultural sector was one of the most sensitive topics. This resulted first of all from the asymmetry in the level of protection of agricultural markets in the EU and the USA, correlated with considerable differences in the production potential of agriculture and the food industry in these countries [22-25]. In the EU-USA relations, a 2.5-fold lowering of tariff barriers in the access to agricultural markets was found in the USA [22], which additionally, to a lesser extent, supported domestic production [24]. Results of the performed projections confirmed expectations consistent with integration theory. Thus, a consequence of liberalization in the bilateral trade of the EU and the USA a stronger impulse for an increase in exports, both total and for agri-food products, might be manifested in the USA, which, prior to the establishment of the preferential trade area, used a lower level of market protection. In terms of the discrepancy on the level of tariffs for agricultural and non-agricultural products, greater differences in the dynamics of the increase in export in the analyzed economies might be found at the meso- rather than macroeconomic level. However, in view of the relatively low importance of the transatlantic trade partner, a strong creation of bilateral trade would not imply a significant increase in overall trade in agri-food products.

On the one hand, conclusion of the free trade agreement between the EU and the USA resulting in the elimination of tariffs and assurance of greater regulatory cohesion would offer a chance for the development of bilateral export and better utilization of the transatlantic market potential, followed by the strengthening of the position of both trade partners on the world market. On the other hand-at the sector level一this would raise concerns related with the potential lowering of food safety and environmental protection standards, as well as the growing competitive pressure on the part of American producers and food exporters taking advantage of the easier access to the European Single Market. When analyzing the course of the previous negotiations and the approach of the EU and the USA in the modification of the trade policy, the complete elimination of tariff barriers in trade in agri-food products between the EU and the USA is doubtful. A more probable solution seems to be provided by the limited liberalization of trade in the so-called sensitive products as well as establishment of several duty-free and tariff quotas. In turn, in view 
of the number of already imposed non-tariff barriers and activity of both partners in the initiation of actions to impose new ones [26], as well as considering disputes concerning sanitary and phytosanitary standards reaching any consensus in this respect will be difficult.

When evaluating the consequences of a potential transatlantic agreement for the EU agri-food sector it needs to be stressed that the ability to gain benefits from preferential trade conditions and the development of export onto the American market would require producers to face competition of specialized, large-area American farms having price and efficiency advantages. At a high level of protection of the agricultural market, agricultural producers in the EU are not subjected to a significant, direct competitive pressure from the US agricultural sector. In this context a question may be raised: What is the current level of competitiveness of the EU agri-food sector in trade with the USA and will the conclusion of the potential partnership agreement contribute to a better utilization of the potential of the transatlantic market, or rather it would constitute a real threat and pose a risk of weakening the competitive position of EU food producers?

\subsection{International Competitiveness of the Agri-Food Sector in the EU Countries}

The problem of competitiveness of the agri-food sector in the case of the EU countries is frequently investigated both in terms of the production potential and productivity of agriculture $[24,25,27-36]$, as well as international competitive position of the agri-food sector [37-44]. In view of the limited access to comprehensive data and information comparable on the international scale, analyses of the competitive potential and competitive capacity of the food industry are conducted relatively rarely [45-49]. Most studies conducted to date have concerned the competitive position of the EU agri-food sector in global trade $[37,39,40,42-44]$ or competitiveness of agri-food sectors in individual EU member countries in the intraregional trade [38,50]. Referring to transatlantic relations, the most frequently conducted comparative analyses concerning competitiveness of the agri-food sector in the EU and the USA concern world trade [44,49]. Moreover, comparative advantages of the USA were also investigated in the case of exports of selected plant raw materials on the European Single Market [51] as well as comparative advantages of the Polish agri-food sector on the US market [52]. In contrast, the problem of identification of comparative advantages of the EU agri-food sector on the US market was neglected. Hence, this paper fills the existing research gap in the field of competitiveness of transatlantic trade in agri-food products.

The added value of these investigations is manifested not only on the purely scientific level, but also in terms of the applied methodology. The starting point in studies on competitiveness stemming from the international trade is provided by the concept of comparative advantage. It should be emphasized here that the development of contemporary theories of trade did not limit the importance of the classical concept for comparative advantages when explaining the directions of export specialization of individual countries [52]. The concept of the comparative advantage postulates that with assumptions of free, unrestricted trade and perfectly competitive markets, each country should specialize in the production of a good, for which it has a relative cost advantage or, in other words, lower opportunity costs of producing the same commodities among countries $[53,54]$. Indicators revealing comparative advantage are particularly useful when measuring international competitiveness at the level of a national economy sector. Although they are not capable of indicating the source of the advantage, they provide a clear picture of competitive standing [55]. Moreover, they are additionally useful because they make it possible to compare the analyzed sector with another considering both the demand and supply of a given product, as well as marketing and transport or shipping costs [56].

Studies conducted to date frequently used one of the indicators of revealed comparative advantages, i.e., the Balassa Revealed Comparative Advantage Index (RCA), which is a ratio of the share of export of the analyzed product in world/regional trade to the share of export of the entire sector in world/regional trade [57]. This measure in the analyses of international competitive position of the agri-food sector was applied by previous 
studies [58-60]. A drawback of the Balassa index is connected with the estimation of comparative advantages only based on the value of exports. Thus, more objective results of analyses are provided by the approaches using the Vollrath Revealed Competitiveness Index (RC), which is a difference of natural logarithms of the revealed comparative advantages in export $(\mathrm{RCA}=\mathrm{RXA})$ and the index established in an analogous manner for Revealed Comparative Advantages in Import (RMA). In this way, the import and export situation of a given country is considered at the same time [61]. The RC index together with the Lafay Trade Balance Index (TBI), which describes the nature of the trade balance was used by previous research [62,63]. Moreover, estimates of comparative advantages referring to the approach proposed by Vollrath were conducted by many researchers $[50,64-68]$.

A weakness of RCA is also connected with its non-symmetric distribution and a lack of a finite upper limit $[60,69]$. In order to eliminate this problem several modifications have been developed for the Balassa index formula, providing its symmetric distribution [70,71] One of these solutions is the Revealed Symmetric Comparative Advantage (RSCA). The RCA correction leading to the definition of this index was proposed by [72] and [73]. The application of this measure together with TBI makes it possible to construct the matrix providing a synthetic assessment of the competitive position of an analyzed country in trade with specific products or groups of products on selected reference markets. Such a methodological approach was proposed for the first time by Widodo [74], and it has been used to assess specialization and competitive performance of the agricultural trade for Russia [75], the Czech Republic [76], and African nations with the EU [77,78]. To specify transatlantic relations, this method was applied by [52] to identify the comparative advantages of the Polish agri-food sector on the US market. For the EU, the USA ranks first among non-EU countries as an export-import partner of agri-food products [79]. However, the competitiveness of the EU agri-food sector in transatlantic trade has never before been assessed in such a systematic way. The presented analysis addresses this gap and offers the product mapping of selected EU agri-food products exported to the US market.

\section{Materials and Methods}

This study used statistical data from the Comext-Eurostat database [79], containing values of bilateral trade in agri-food products of the EU and the USA in the years 2010 and 2020. Such a specified timeframe of the study makes it possible to identify long-term changes taking place in the level of ex post comparative advantages and on this basis to assess potential competitive capacity of the analyzed countries in the future. Values of turnover were established using the principle of mirror statistics, which means that the US import from the EU is equal in value to the EU export to the USA (for more on mirror statistics see e.g., [80]).

The following were used in the analysis of comparative advantages:

1. The Balassa Revealed Comparative Advantage Index (RCA) [57]:

$$
R C A_{i j}=R X A_{i j}=\left(X_{i j} / X_{i k}\right) /\left(X_{n j} / X_{n k}\right)
$$

where: $X$-export, $i$-analyzed country, $j$-analyzed product/group of products, $k$-all goods, $n$-reference country/countries. Values of RCA greater than 1 denote an advantageous competitive situation, while lower values indicate a lack of comparative advantages.

2. The Vollrath Revealed Competitiveness Index (RC), which positive value denotes a competitive advantage, while a negative value shows a disadvantageous competitive situation [61]:

$$
R C_{i j}=\ln \left(R X A_{i j}\right)-\ln \left(R M A_{i j}\right)
$$

where:

$$
R M A_{i j}=\left(M_{i j} / M_{i k}\right) /\left(M_{n j} / M_{n k}\right)
$$


3. The Revealed Symmetric Comparative Advantage index (RSCA), which assumes values in the range of $[-1,1]$. Values of RSCA lesser than zero denote a lack of comparative advantage, while greater values show such an advantage [72]:

$$
R S C A_{i j}=\left(R C A_{i j}-1\right)\left(R C A_{i j}+1\right)
$$

4. The Lafay Trade Balance Index (TBI) [81]:

$$
T B I_{i j}=\left(X_{i j}-M_{i j}\right) /\left(X_{i j}+M_{i j}\right)
$$

Values of TBI, similarly as RSCA, are contained in the range of $[-1,1]$. Positive values of this index denote export specialization of the analyzed country and are typically a sign of trade balance surplus. In turn negative values show a lack of specialization and the net importer position of a given country in relation to a specific product or group of products. The symmetric distribution of values for RSCA and TBI makes it possible to construct a matrix mapping analyzed products in four groups differing in the level of comparative advantages (RSCA) and the degree of export specialization (TBI) (Figure 1).

\begin{tabular}{|c|c|}
\hline Group B & Group A \\
Comparative advantage & Comparative advantage \\
Net-importer & Net-exporter \\
$($ RSCA $>0$ i TBI $<0)$ & $($ RSCA $>0$ i TBI $>0)$ \\
\hline Group D & Group C \\
Comparative disadvantage & Comparative disadvantage \\
Net-importer & Net-exporter \\
$($ RSCA $<0$ i TBI $<0)$ & $($ RSCA $<0$ i TBI $>0)$ \\
\hline
\end{tabular}

Figure 1. Mapping of products depending on the level of comparative advantages and the degree of export specialization according to Widodo. Source: Widodo [74].

Using the Widodo approach, based on values of bilateral trade in 2010 and 2020, selected agri-food products exported from the EU onto the US market were mapped. The competitive position of the EU agri-food sector in transatlantic trade was evaluated in the context of potential changes in institutional conditions for trade resulting from the conclusion of an agreement establishing an EU-USA free trade area. The Widodo matrices were constructed for groups of products, which share in the structure of exports or imports to/from the USA within at least one year covered by the study was $5 \%$ or more. The analysis of comparative advantages was preceded by the analysis of the commodity structure of bilateral agri-food trade between the EU and the USA.

\section{Results and Discussion}

\subsection{Commodity Structure of the Agri-Food Trade between the EU and the US}

In the years 2010-2020 the value of exports in agri-food products from the EU countries to the USA increased 2-fold, reaching in the last investigated year the value of $€ 21.2$ billion. The increase in food imports was less dynamic. In 2020 the value of imports of agricultural products and products of the food industry from the USA to the EU was $€ 9.7$ billion and it was slightly over 50\% higher than in 2010 (Table 3). What is significant, over the entire analyzed period the EU took the net exporter position in relation to agri-food products to 
the USA, while the recorded positive trade balance increased from $€ 4.2$ billion in 2010 to reach $€ 11.5$ billion in 2020 .

Table 3. Value and trade balance of agri-food trade between the EU and the US in 2010 and 2020 by the Combined Nomenclature (CN) sections ( $€$ million).

\begin{tabular}{|c|c|c|c|c|c|c|c|c|}
\hline \multirow{3}{*}{ Section } & \multicolumn{3}{|c|}{ Export } & \multicolumn{3}{|c|}{ Import } & \multicolumn{2}{|c|}{ Trade Balance } \\
\hline & 2010 & & 2020 & 2010 & & 2020 & 2010 & 2020 \\
\hline & \multicolumn{2}{|c|}{$€$ Million } & $2010=100^{a}$ & \multicolumn{2}{|c|}{$€$ Million } & $2010=100^{a}$ & \multicolumn{2}{|c|}{$€$ Million } \\
\hline I. Live animals; animal products & 1095.8 & 2403.3 & 1307.6 & 891.1 & 1099.8 & 208.7 & 204.7 & 1303.5 \\
\hline II. Vegetable products & 1293.9 & 2477.9 & 1184.0 & 3158.5 & 5548.2 & 2389.7 & -1864.6 & -3070.3 \\
\hline $\begin{array}{l}\text { III. Animal or vegetable fats and oils } \\
\text { and their cleavage products; prepared } \\
\text { edible fats; animal or vegetable waxes }\end{array}$ & 637.4 & 1258.3 & 620.8 & 187.5 & 256.4 & 68.8 & 449.9 & 1001.9 \\
\hline $\begin{array}{l}\text { IV. Prepared foodstuffs; beverages, } \\
\text { spirits and vinegar; tobacco and } \\
\text { manufactured tobacco substitutes }\end{array}$ & 7598.8 & $15,081.3$ & 7482.6 & 2190.2 & 2811.2 & 621.0 & 5408.5 & $12,270.1$ \\
\hline Total & $10,625.9$ & $21,220.9$ & $10,595.0$ & 6427.4 & 9715.6 & 3288.3 & 4198.5 & $11,505.3$ \\
\hline
\end{tabular}

Note: ${ }^{\text {a }}$-growth rate in the years 2010-2020 (\%). Source: [79], the author's elaboration.

In the export of agri-food products from the EU to the USA prepared foodstuffs, alcoholic beverages and tobacco products predominated. In 2020 the value of exports for these products on the American market exceeded $€ 15$ billion, which constituted over $70 \%$ total agri-food exports from the EU to the USA (Table 3). Each year imports of this assortment group from the USA were from 3.5- to over 5-fold smaller. In the years 2010-2020 the rate of increase in exports for this Combined Nomenclature (CN) section was faster than the rate of increase in imports. Thus, the EU systematically obtained a growing trade surplus, which in the last investigated year amounted to $€ 12.3$ billion and it was by $€ 800$ million higher than in the total agri-food trade.

The EU also strengthened its position of a net exporter of live animals and animal origin products as well as fats and oils to the USA. In 2020 the surplus of export over import in both sections exceeded $€ 1$ billion and it was almost 6.5 -fold and over 2-fold greater than in 2010 (Table 3). The importance of this assortment in the structure of agri-food trade with the USA was nevertheless much smaller than in the case of processed food. In 2020 fats and oils constituted approximately $6 \%$ total export and 3\% import, while for live animals and animal origin products it was about $11 \%$ both for export and import. A comparable share in export $(12 \%)$, but much higher in import (57\%) was recorded for plant origin products, in the case of which the EU recorded a deepening turnover deficit. In the last analyzed year expenditure on imports of vegetable products from the USA was greater than income obtained by the EU for exports of this assortment onto the American market by approximately $€ 3$ billion, i.e., by $65 \%$ more than in 2010 . In bilateral relations this indicates a more indispensable character of imports from the USA for the EU than vice versa.

This observation is confirmed by a more detailed analysis of the commodity structure in the agri-food trade of the UE with the USA (Table 4). In 2010 fruits and nuts (pistachios and almonds) and oil seeds (mainly soy grown in Europe to a limited extent) jointly accounted for approximately $40 \%$ and in $202050 \%$ total imports of agri-food products from the USA to the EU. In turn, the turnover deficit generated in trade with these products was growing. In the last analyzed year in bilateral trade in fruits and nuts the value of imports to the EU exceeded the value of export to the USA by $€ 2.4$ billion, while in the trade in oil seeds it was by $€ 1.8$ billion, which jointly reduced the trade balance of the EU with the USA by over $35 \%$. Apart from these two commodity groups, negative but lower in values and decreasing in the years 2010-2020 trade balance was also recorded in trade in fish, crustaceans and mollusks ( $€ 305$ million in 2020), tobacco and tobacco products (€195 million) as well as residues and waste from the food industries ( $€ 36$ million). 
Table 4. Commodity structure of agri-food trade between the EU and the US in 2010 and 2020 by the Harmonized System (HS) chapters.

\begin{tabular}{|c|c|c|c|c|c|c|c|c|c|c|c|}
\hline \multirow[b]{3}{*}{ HS } & \multirow[b]{3}{*}{ Product Group } & \multicolumn{5}{|c|}{2010} & \multicolumn{5}{|c|}{2020} \\
\hline & & \multicolumn{2}{|c|}{ Export } & \multicolumn{2}{|c|}{ Import } & \multirow{2}{*}{$\begin{array}{c}\begin{array}{c}\text { Trade } \\
\text { Balance } \\
(€\end{array} \\
\text { Million) }\end{array}$} & \multicolumn{2}{|c|}{ Export } & \multicolumn{2}{|c|}{ Import } & \multirow{2}{*}{$\begin{array}{c}\text { Trade } \\
\text { Balance } \\
(€ \\
\text { Million) }\end{array}$} \\
\hline & & $\begin{array}{c}\text { Value } \\
(€ \\
\text { Million) }\end{array}$ & $\begin{array}{l}\text { Share } \\
(\%)\end{array}$ & $\begin{array}{c}\text { Value } \\
(€ \\
\text { Million) }\end{array}$ & $\begin{array}{l}\text { Share } \\
(\%)\end{array}$ & & $\begin{array}{c}\text { Value } \\
(€ \\
\text { Million) }\end{array}$ & $\begin{array}{l}\text { Share } \\
(\%)\end{array}$ & $\begin{array}{c}\text { Value } \\
\text { ( } \\
\text { Million) }\end{array}$ & $\begin{array}{l}\text { Share } \\
(\%)\end{array}$ & \\
\hline 01 & Live animals & 150.7 & 1.4 & 69.0 & 1.1 & 81.7 & 349.1 & 1.6 & 85.8 & 0.9 & 263.3 \\
\hline 02 & Meat and edible meat offal & 178.8 & 1.7 & 97.7 & 1.5 & 81.1 & 404.7 & 1.9 & 158.5 & 1.6 & 246.2 \\
\hline 03 & $\begin{array}{l}\text { Fish and crustaceans, molluscs and other } \\
\text { aquatic invertebrates }\end{array}$ & 147.1 & 1.4 & 634.4 & 9.9 & -487.3 & 439.7 & 2.1 & 744.8 & 7.7 & -305.1 \\
\hline 04 & Dairy produce; birds' eggs; natural honey & 588.5 & 5.5 & 46.4 & 0.7 & 542.2 & 1105.3 & 5.2 & 34.5 & 0.4 & 1070.7 \\
\hline 05 & $\begin{array}{l}\text { Products of animal origin, not elsewhere } \\
\text { specified }\end{array}$ & 30.7 & 0.3 & 43.6 & 0.7 & -12.9 & 104.6 & 0.5 & 76.1 & 0.8 & 28.5 \\
\hline 06 & Live trees and other plants & 198.9 & 1.9 & 76.0 & 1.2 & 122.8 & 227.5 & 1.1 & 56.6 & 0.6 & 170.9 \\
\hline 07 & Edible vegetables and certain roots and tubers & 135.5 & 1.3 & 118.4 & 1.8 & 17.1 & 376.1 & 1.8 & 236.2 & 2.4 & 139.8 \\
\hline 08 & Edible fruit and nuts & 104.7 & 1.0 & 1166.7 & 18.2 & -1062.1 & 151.0 & 0.7 & 2543.7 & 26.2 & -2392.7 \\
\hline 09 & Coffee, tea, mate and spices & 377.6 & 3.6 & 13.9 & 0.2 & 363.8 & 489.2 & 2.3 & 43.3 & 0.4 & 445.8 \\
\hline 10 & Cereals & 24.8 & 0.2 & 373.6 & 5.8 & -348.7 & 80.2 & 0.4 & 306.7 & 3.2 & -226.5 \\
\hline 11 & Products of the milling industry & 145.4 & 1.4 & 16.1 & 0.3 & 129.2 & 344.1 & 1.6 & 18.1 & 0.2 & 326.0 \\
\hline 12 & Oil seeds and oleaginous fruits & 150.1 & 1.4 & 1280.3 & 19.9 & -1130.3 & 378.3 & 1.8 & 2213.4 & 22.8 & -1835.1 \\
\hline 13 & $\begin{array}{l}\text { Lac; gums, resins and other vegetable saps and } \\
\text { extracts }\end{array}$ & 155.8 & 1.5 & 101.0 & 1.6 & 54.8 & 416.6 & 2.0 & 127.8 & 1.3 & 288.8 \\
\hline 14 & $\begin{array}{l}\text { Vegetable planting materials; vegetable } \\
\text { products not elsewhere specified }\end{array}$ & 1.1 & 0.0 & 12.5 & 0.2 & -11.4 & 15.0 & 0.1 & 2.4 & 0.0 & 12.6 \\
\hline 15 & Animal or vegetable fats and oils & 637.4 & 6.0 & 187.5 & 2.9 & 449.9 & 1258.3 & 5.9 & 256.4 & 2.6 & 1001.9 \\
\hline 16 & Preparations of meat or of fish & 117.9 & 1.1 & 44.9 & 0.7 & 73.0 & 279.1 & 1.3 & 38.3 & 0.4 & 240.8 \\
\hline 17 & Sugars and sugar confectionery & 156.8 & 1.5 & 35.4 & 0.6 & 121.3 & 438.8 & 2.1 & 57.8 & 0.6 & 381.0 \\
\hline 18 & Cocoa and cocoa preparations & 622.0 & 5.9 & 15.1 & 0.2 & 606.8 & 707.8 & 3.3 & 38.1 & 0.4 & 669.7 \\
\hline 19 & Preparations of cereals & 490.2 & 4.6 & 38.7 & 0.6 & 451.5 & 1467.9 & 6.9 & 54.0 & 0.6 & 1413.9 \\
\hline 20 & Preparations of vegetables, fruit or nuts & 538.3 & 5.1 & 189.7 & 3.0 & 348.6 & 1283.9 & 6.1 & 185.7 & 1.9 & 1098.2 \\
\hline 21 & Miscellaneous edible preparations & 322.6 & 3.0 & 299.6 & 4.7 & 23.0 & 1102.2 & 5.2 & 656.9 & 6.8 & 445.3 \\
\hline 22 & Beverages, spirits and vinegar & 5178.0 & 48.7 & 740.7 & 11.5 & 4437.3 & 9311.8 & 43.9 & 1058.7 & 10.9 & 8253.1 \\
\hline 23 & $\begin{array}{l}\text { Residues and waste from the food industries; } \\
\text { prepared animal fodder }\end{array}$ & 93.9 & 0.9 & 514.9 & 8.0 & -421.0 & 398.3 & 1.9 & 434.7 & 4.5 & -36.4 \\
\hline \multirow[t]{2}{*}{24} & Tobacco and manufactured tobacco substitutes & 79.2 & 0.7 & 311.2 & 4.8 & -232.0 & 91.6 & 0.4 & 287.0 & 3.0 & -195.4 \\
\hline & Total & $10,625,9$ & 100.0 & 6427.4 & 100.0 & 4198.5 & $21,220.9$ & 100.0 & 9715.6 & 100.0 & $11,505.3$ \\
\hline
\end{tabular}

Source: [79], the author's elaboration.

The above-mentioned product groups along with non-alcoholic beverages and spirits and cereals were other important commodity groups in import from the USA to the EU. In export of agri-food products to the American market approximately $45-50 \%$ total exports comprised non-alcoholic and alcoholic beverages (wines, cognacs, beer and whisky), while approximately $5-7 \%$ accounted each for cereal preparations (e.g., confectionary and pasta), preparations of fruit and vegetable, fats and oils (primarily olive oil), miscellaneous edible preparations and dairy products (Table 4). It results from the above that a characteristic feature of agri-food export from the EU to the USA is a low share of staple agricultural raw materials at a high share of processed food products and beverages, mainly spirits. It needs to be stressed here that only beverages and spirits provided the EU with a very high surplus in trade in 2020 , reaching $€ 8.3$ billion and accounting for over $70 \%$ of the positive total trade balance. Considering the six groups of products, which share in the agri-food exports from the EU to the USA exceeded 5\%, the positive trade balance provided by them in 2020 amounted to $€ 13.3$ billion, i.e., by over $15 \%$ more than the surplus in total trade, reduced by the import of fruits and nuts and oil seeds.

When analyzing the commodity structure of agri-food trade of the EU with the USA, it develops according to the inter-industry model due to the small complementarity structure of agricultural production from similar climates. As a result, in the USA, a very small demand is observed for agricultural products of the temperate climate zone coming from 
the EU, which are produced more efficiently and cheaper in the USA and which constitute the export surplus of this country. The inter-industry character of trade in agri-food products of the EU with the USA was confirmed by the results of studies conducted by [82]. They showed that in the years 2007-2018 this type of specialization in trade in agri-food products of the EU with the USA was strengthened and deepened, while intra-industry trade was observed, first of all in trade in varied premium products, which may hardly be substituted with other products. In view of the above it may be assumed that it is in this type of trade that we may find the greatest chance for the development of food exports from the EU countries on the American market. Low intensity of intra-industry trade in agri-food products of the EU with the USA may in turn be justified e.g., by the considerable distance and the difference in the absolute size of the markets of the trade partners, as well as varied levels of economic development of the analyzed countries [83-86]. In reference to the analysis by [87] it may be assumed that an increase in the degree of intra-industry specialization might be promoted by the affiliation of the investigated countries to the same preferential trade area.

\subsection{Product Mapping of the EU Agri-Food Trade with the US}

Based on the established values of the Balassa Revealed Comparative Advantage Index (RCA), in 2020 the EU had revealed comparative advantages (RCA > 1) in export to the US market in all major product groups in the structure of exports (the share in the structure of export over 5\%), except for miscellaneous edible preparations (Table 5). The most advantageous competitive situation was recorded in the export of dairy products (HS 04-chapter 04 of the Harmonized System) and products of the milling industry (HS 19). In the years 2010-2020 the EU strengthened its competitive position on the American market, which was also reflected in the improvement of the obtained trade surplus (Trade Balance Index-TBI). High comparative advantages and the increasing positive trade balance of the EU was also generated in transatlantic trade in non-alcoholic and alcoholic beverages (HS 22) as well as preparations of fruits and vegetables (HS 20). However, the level of comparative advantages decreased in the trade in the first group of products, providing the EU with almost $45 \%$ total income from food exports to the USA, despite an increase in its values. The weakening competitive position on the American market was also observed in trade in coffee, tea and spices (HS 09) as well as cocoa and cocoa preparations (HS 18), which in the structure of exports of agri-food products to the USA accounted for approximately $2-3 \%$ each.

Among the other products of significant importance in the structure of export to the USA (above 1.5\%), the EU was not capable to compete in the trade in fish, crustaceans and molluscs (HS 03), fruits and nuts (HS 08), oil seeds (HS 12) and residues and wastes from the food industry (HS 23). Next to beverages (HS 22) and miscellaneous edible preparations (HS 21) they were products of greatest importance in the structure of imports of agri-food products from the USA and these, for which symptoms of intra-industry trade could be detected, undertaken to expand the assortment offered on the EU market or required to fully satisfy demand on the part of the European Single Market. As a result, in the case of trade in four above-mentioned assortment groups (fish, crustaceans and mollusks, fruits and nuts, oil seeds as well as residues and wastes from the food industry) the EU was a net importer. It results from the above that while in terms of traditional export specialties the EU reached in its trade with the USA an advantageous competitive position, it was either weaker or the EU showed no advantage in the trade in products, which simultaneous import was indispensable. 
Table 5. Evaluation of the comparative advantages of the EU agri-food sector in relation to the US market in 2010 and 2020 by the Harmonized System (HS) chapters.

\begin{tabular}{|c|c|c|c|c|c|c|c|c|c|}
\hline \multirow{2}{*}{ HS } & \multirow{2}{*}{ Product Group } & \multicolumn{4}{|c|}{2010} & \multicolumn{4}{|c|}{2020} \\
\hline & & $\mathrm{RCA}^{\mathrm{a}}$ & $\mathrm{RC}^{\mathrm{b}}$ & RSCA $^{c}$ & TBI ${ }^{d}$ & RCA $^{a}$ & $\mathbf{R C}^{\mathbf{b}}$ & RSCA $^{c}$ & TBI ${ }^{d}$ \\
\hline 01 & Live animals & 1.32 & 0.56 & 0.14 & 0.37 & 1.86 & 1.24 & 0.30 & 0.61 \\
\hline 02 & Meat and edible meat offal & 1.11 & 0.20 & 0.05 & 0.29 & 1.17 & 0.31 & 0.08 & 0.44 \\
\hline 03 & $\begin{array}{l}\text { Fish and crustaceans, molluscs and other aquatic } \\
\text { invertebrates }\end{array}$ & 0.14 & -3.93 & -0.75 & -0.62 & 0.27 & -2.62 & -0.57 & -0.26 \\
\hline 04 & Dairy produce; birds' eggs; natural honey & 7.68 & 4.08 & 0.77 & 0.85 & 14.65 & 5.37 & 0.87 & 0.94 \\
\hline 05 & Products of animal origin, not elsewhere specified & 0.43 & -1.71 & -0.40 & -0.17 & 0.63 & -0.93 & -0.23 & 0.16 \\
\hline 06 & Live trees and other plants & 1.58 & 0.92 & 0.23 & 0.45 & 1.84 & 1.22 & 0.30 & 0.60 \\
\hline 07 & Edible vegetables and certain roots and tubers & 0.69 & -0.74 & -0.18 & 0.07 & 0.73 & -0.63 & -0.16 & 0.23 \\
\hline 08 & Edible fruit and nuts & 0.05 & -5.83 & -0.90 & -0.84 & 0.03 & -7.21 & -0.95 & -0.89 \\
\hline 09 & Coffee, tea, mate and spices & 16.49 & 5.61 & 0.89 & 0.93 & 5.17 & 3.28 & 0.68 & 0.84 \\
\hline 10 & Cereals & 0.04 & -6.43 & -0.92 & -0.88 & 0.12 & -4.24 & -0.79 & -0.59 \\
\hline 11 & Products of the milling industry & 5.45 & 3.39 & 0.69 & 0.80 & 8.73 & 4.33 & 0.79 & 0.90 \\
\hline 12 & Oil seeds and oleaginous fruits & 0.07 & -5.29 & -0.87 & -0.79 & 0.08 & -5.10 & -0.85 & -0.71 \\
\hline 13 & Lac; gums, resins and other vegetable saps and extracts & 0.93 & -0.14 & -0.03 & 0.21 & 1.49 & 0.80 & 0.20 & 0.53 \\
\hline 14 & $\begin{array}{l}\text { Vegetable planting materials; vegetable products not } \\
\text { elsewhere specified }\end{array}$ & 0.05 & -5.82 & -0.90 & -0.83 & 2.90 & 2.13 & 0.49 & 0.73 \\
\hline 15 & Animal or vegetable fats and oils & 2.06 & 1.44 & 0.35 & 0.55 & 2.25 & 1.62 & 0.38 & 0.66 \\
\hline 16 & Preparations of meat or of fish & 1.59 & 0.92 & 0.23 & 0.45 & 3.34 & 2.41 & 0.54 & 0.76 \\
\hline 17 & Sugars and sugar confectionery & 2.68 & 1.97 & 0.46 & 0.63 & 3.47 & 2.49 & 0.55 & 0.77 \\
\hline 18 & Cocoa and cocoa preparations & 24.86 & 6.43 & 0.92 & 0.95 & 8.51 & 4.28 & 0.79 & 0.90 \\
\hline 19 & Preparations of cereals & 7.66 & 4.07 & 0.77 & 0.85 & 12.44 & 5.04 & 0.85 & 0.93 \\
\hline 20 & Preparations of vegetables, fruit or nuts & 1.72 & 1.08 & 0.26 & 0.48 & 3.17 & 2.30 & 0.52 & 0.75 \\
\hline 21 & Miscellaneous edible preparations & 0.65 & -0.86 & -0.21 & 0.04 & 0.77 & -0.53 & -0.13 & 0.25 \\
\hline 22 & Beverages, spirits and vinegar & 4.23 & 2.88 & 0.62 & 0.75 & 4.03 & 2.79 & 0.60 & 0.80 \\
\hline 23 & $\begin{array}{l}\text { Residues and waste from the food industries; prepared } \\
\text { animal fodder }\end{array}$ & 0.11 & -4.41 & -0.80 & -0.69 & 0.42 & -1.74 & -0.41 & -0.04 \\
\hline 24 & Tobacco and manufactured tobacco substitutes & 0.15 & -3.74 & -0.73 & -0.59 & 0.15 & -3.85 & -0.75 & -0.52 \\
\hline
\end{tabular}

Note: ${ }^{\mathrm{a}}$-Revealed Comparative Advantage Index; ${ }^{\mathrm{b}}$-Revealed Competitiveness Index; ${ }^{\mathrm{c}}$ - Revealed Symmetric Comparative Advantage Index; ${ }^{\mathrm{d}}$-Trade Balance Index. Source: [79], the author's calculations.

Similar conclusions are provided by the analysis of values of the Vollrath Revealed Competitiveness Indexes (RC), as well as mapping of products according to the level of Revealed Symmetric Comparative Advantages (RSCA) and the Trade Balance Index (TBI) (Figure 2, Table 6). In both analyzed years the groups of products, in which trade the EU was generating the highest comparative advantages and taking the position of a net exporter to the US market (group A) accounted jointly for over $85 \%$ total exports of agri-food products and ensured trade surplus of $€ 7.8$ billion in 2010 and $€ 15.9$ billion in 2020. In the last of the analyzed years the commodity groups, in which the EU had no comparative advantages, but was a net exporter (group C) in the structure of exports of agri-food products to the USA accounted for approximately $10 \%$. In turn these assortment groups, in the trade of which the lack of comparative advantages was accompanied by a lack of export specialization and a trade deficit constituted only $5 \%$ exports, but as much as $60 \%$ imports (group D). The negative trade balance observed in the analyzed period in trade of the latter products increased and in 2020 amounted to $€ 4.8$ billion, which decreased the positive total trade balance by over $40 \%$. It is also important that, in the structure of bilateral trade between the EU and the US, no products either in 2010 or in 2020 were identified as those, which, despite the high level of comparative advantages, generate a trade deficit (group B). 


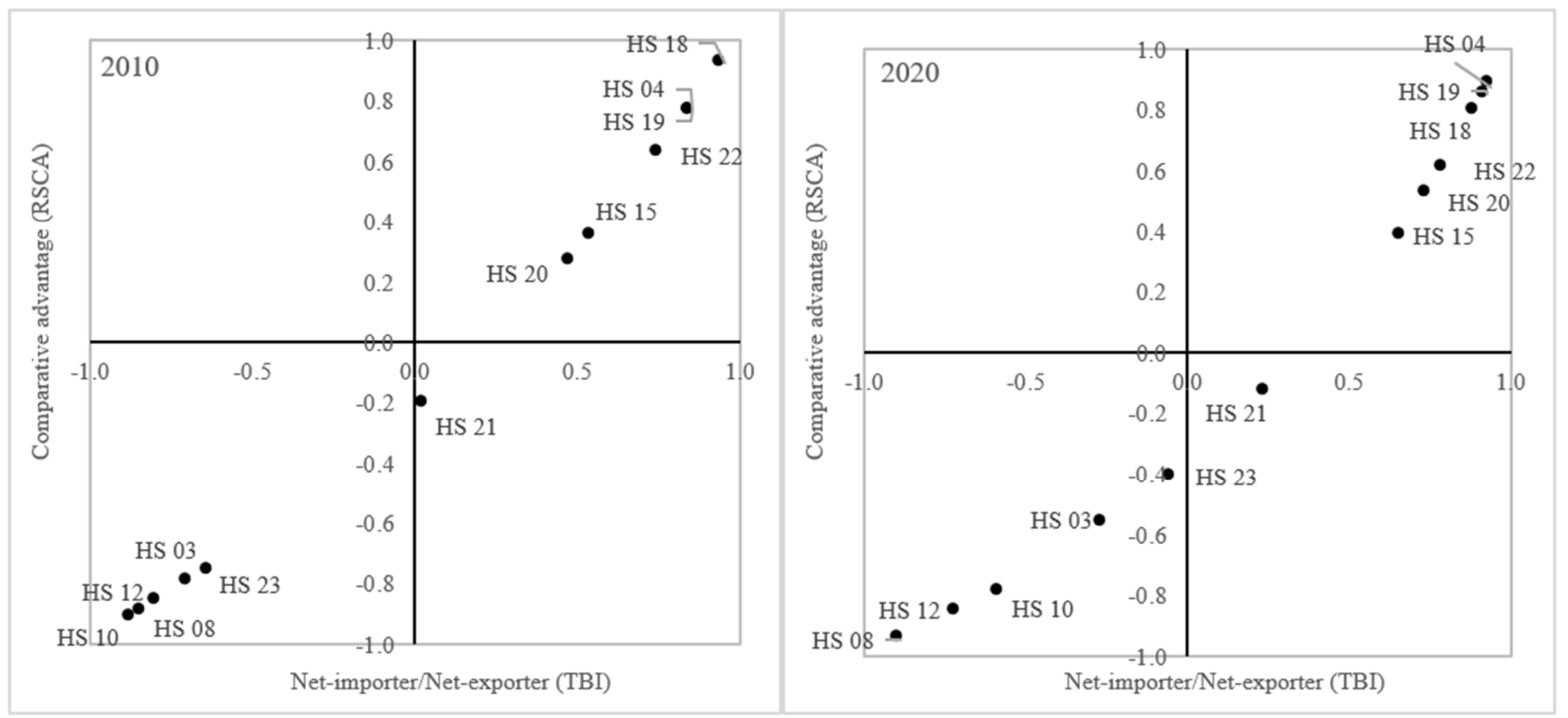

Figure 2. Mapping of selected groups of agri-food products exported from the EU to the USA depending on the level of comparative advantages and the degree of export specialization in the years 2010 and 2020 (the Widodo approach). Note: the figures present only the groups of products, which share in the structure of export or import to/from the USA in at least one analyzed year amount to $\min$. 5\%. Source: The author's elaboration based on data from Table 5.

Table 6. Shares of individual groups of products resulting from mapping by the Widodo method in agri-food trade of the EU with the USA and trade balance for these groups in the years 2010 and $2020(\%)$.

\begin{tabular}{|c|c|c|c|c|c|c|}
\hline \multirow[b]{2}{*}{ Group } & \multicolumn{3}{|c|}{2010} & \multicolumn{3}{|c|}{2020} \\
\hline & $\begin{array}{l}\text { Share in Total } \\
\text { Export }(\%)\end{array}$ & $\begin{array}{l}\text { Share in Total } \\
\text { Import }(\%)\end{array}$ & $\begin{array}{l}\text { Trade Balance } \\
\text { (€ Million) }\end{array}$ & $\begin{array}{l}\text { Share in Total } \\
\text { Export }(\%)\end{array}$ & $\begin{array}{l}\text { Share in Total } \\
\text { Import }(\%)\end{array}$ & $\begin{array}{l}\text { Trade Balance } \\
\text { (€ Million) }\end{array}$ \\
\hline Group A & 88.3 & 24.4 & 7809.2 & 85.3 & 22.8 & $15,883.0$ \\
\hline Group B & $x$ & $x$ & $x$ & $x$ & $x$ & $x$ \\
\hline Group C & 5.8 & 8.1 & 94.9 & 9.8 & 17.4 & 381.7 \\
\hline Group D & 5.9 & 67.5 & -3705.6 & 4.9 & 59.8 & -4759.4 \\
\hline
\end{tabular}

Source: The author's calculations based on data from Table 4 .

In the years 2010-2020 the structure of bilateral trade in agri-food products of the EU with the USA according to the variants of competitive position was stable. In absolute terms values of export for products characterized by the highest level of competitiveness increased and the obtained trade surplus was growing dynamically (Table 4). On this basis it may be stated that comparative advantages reached by the EU on the US market were sources of an advantageous export specialization, while the commodity structure of foreign trade in EU agri-food products with the USA was rational. Considering the estimates presented by [20] indicating a transatlantic agreement with a 2.5-fold increase in dairy product exports and an $80 \%$ increase in processed food exports (e.g., cereals, preparations of fruits and vegetables), a potential further strengthening of the EU competitive position on the American market may be expected.

Establishment of the free trade area and reduction of the high tariffs applied in import of dairy products from the EU to the USA [88] might contribute to the generation of a cost advantage by EU producers over their competitors from New Zealand and Argentina. However, a condition, which needs to be met for an increase in export of dairy products from the EU to the USA would be a progressing regulatory cooperation aiming at a 
reduction of restrictive non-tariff barriers used by the USA, resulting in the necessity to ensure equivalence to the standards binding on the American market [20]. Thus, it would be necessary to establish transparent rules for the harmonization and mutual recognition of standards (for more on the subject see e.g., [89]). An additional factor promoting export would be to reach an agreement in the enforcing by the American party protection of EU products with geographical indications. However, it may be speculated with a high degree of probability that it would be extremely difficult.

In many previously negotiated free trade agreements both the EU and the USA imposed their position concerning protection of geographical indications. Detailed regulations in this respect were included in agreements concluded by the EU with South Korea, Singapore, Vietnam, Japan and Canada. The USA defended their concept of a system of trademarks for the protection of geographical indications in the negotiations for the Agreement on Transpacific Partnership [90]. The differences in the negotiation positions results from the discrepancies in the approach to the protection of geographical indications on both sides of the Atlantic. Legal solutions adopted in the USA do not permit protection of some geographic indications protected in the EU. This pertains to products, which names in the USA became generic (household names). According to the American legislature, each producer has the right to use such names, and not-as it is in the EU-the producer of these products, the consistency of which with the specification of geographic indication was confirmed by an accredited certifying agency. As a result, for American entities exporting to the markets of third countries goods with generic names protected in the EU the adoption of the EU system protecting geographical names would mean the necessity to withdraw from those markets (for more on the geographic indication protection systems in the EU and the USA see [91,92]).

Reaching a compromise concerning geographical indications may also offer a chance for the development of exports of some specialty meat preparations. Even despite an over 4-fold and an almost 3-fold increase in exports of red meat and poultry, respectively, as forecasted after the implementation of a free trade agreement [20], it is rather unlikely for the EU to become a major and competitive supplier of these products to the US market (being a producer with particularly low production costs). The EU could nevertheless gain an easier access to the markets of premium products with exceptional quality and value ascribed to the geographical origin of these goods. Similarly, as in the trade of dairy products, also in this case a reduction in tariffs would still have to accompany liberalization of non-tariff barriers, presently faced by exporters from the EU.

While the development of bilateral trade in preparations of fruits and vegetables in a free trade area should not be disturbed, greater problems could be experienced when trading in cereals. The larger scale of production, good soils in the Corn Belt, vast and cheap land in the Wheat Belt, highly mechanized agriculture and an efficient transportation network gives the US a high-cost advantage in the production of cereals, including especially corn and wheat, over the EU [20]. At low world prices the EU tariffs ensure a high level of the EU market protection against imports of medium and low-quality wheat used mainly in the production of animal feeds. In turn, elimination of tariff barriers in imports from the USA might lead to increased imports from the USA both in the case of wheat and maize, although in the latter case the situation to a considerable extent would depend on the direction of the American ethanol policy. However, maintenance of the EU comparative advantages in exports of preparations of cereals does not seem to be threatened. That is because main exported products include bakery and confectionary products and pasta [79], manufactured from edible cereals in the EU bakery sector, which is consolidating and is gaining an advantage resulting from lower costs and processing margins, while it can offer the consumers willing to buy them healthier alternatives at the same time.

Lifting of the discrimination tariff barriers might stop the trend observed since 2010 for the reduction of the level of the EU comparative advantages in export onto the American market in the case of alcoholic beverages, among which wines predominated. Moreover, a significant factor offsetting the lack of balance in the competition conditions on the 
American market and promoting the development of export from the EU may be provided by the uniformity of fiscal measures and excise duties applied at the state level. Currently, domestic wine producers in contrast to their competitors from the EU, are eligible to tax breaks or tax credits [20].

Research results demonstrate that a key role in the creation of future comparative advantages of the EU agri-food sector on the US market might be played by non-tariff barriers to trade. These include geographical indications, sanitary and phytosanitary restrictions, food safety regulations and administrative requirements. As has been mentioned above, using tariff barriers lower than the EU levels and supporting domestic production to a lesser extent $[22,24]$, the USA in the agri-food trade maintain higher levels of non-tariff protection than the EU. The USA are also more active in initiating procedures aiming at the establishment of new non-tariff instruments of market protection [93]. Hence it may be assumed that a reduction in the level of tariff protection for the transatlantic market, with no reduction of non-tariff barriers, would not necessarily lead to the actual lowering of the level of protection, while it might only lead to a change in its structure. This seems to be confirmed by very high estimates of ad valorem equivalents to non-tariff barriers for certain products, markedly higher than the adopted tariffs. In the bilateral trade of the EU with the USA such products include meat, dairy products, cereals as well as fruit and vegetables $[15,20]$.

In view of the difficulties in the quantification and confirmation of the direct effect of non-tariff instruments on the volume and structure of trade (the hidden character of protection), regulatory cooperation constituted a major problem in the transatlantic trade talks. In case of their reinstatement the total elimination of regulatory barriers in trade between the EU and the USA, such as sanitary and phytosanitary measures, technical barriers and geographical indications seem rather unlikely. In such a situation it would be necessary to implement harmonization of the above-mentioned instruments, which in essence would result in one of the parties of the regulatory system binding in the economy of their trade partner. It does not seem likely for any of the parties to the transatlantic trade agreement to be willing to accept such a solution. Another solution would be to construct a new, joint system of standards, which in turn would require time and political will to reach such an agreement.

\section{Conclusions}

Establishment of a free trade area between the EU and the USA within the Transatlantic Trade and Investment Partnership (TTIP) was a key element in transatlantic relations in the 21st century. It was seen as a method to accelerate economic growth of both economies and to stabilize their position in the world economy at the growing competitive pressure on the part of emerging superpowers. The agri-food sector proved to be one of the most difficult areas during the trade talks. Although the problem of competitiveness in the agri-food sector of the EU countries has been investigated in many studies, in relation to the transatlantic relations research has focused mainly on the evaluation of competitive advantages of the EU and the US agri-food sectors in global trade, neglecting the aspect of bilateral relations. Thus, the aim of this paper was to estimate the competitive position of the EU agri-food sector in transatlantic trade considering the conclusion of the agreement establishing the EU-USA free trade area.

It results from the conducted analyses that in the years 2010-2020 comparative advantages gained by the EU on the US market were sources of an advantageous export specialization. This is in line with the classical principle of comparative costs. In view of the forecasted dynamic increase in agri-food export from the EU to the USA caused by possible liberalization of bilateral trade the relatively strong competitive position of the EU on the American market might be maintained or even strengthened. However, such a situation would be determined by the regulatory cooperation progressing with the reduction of tariffs. Due to the complexity of the problem and adherence of both parties to their own standards, reaching a consensus in this respect would be a difficult task. 
Similarly, as in many previously negotiated preferential trade agreements, a key to a compromise is connected not with the readily quantifiable tariff barriers, but rather much more difficult to neutralize "hidden" protection measures, functioning as internal barriers, which are indirectly applicable in the case of imported products. In relation to trade of agri-food products we may observe a tendency to strengthen protectionism together with an increase in the level of economic growth, the level of income per capita and the degree of industrialization of the economy. Both the EU and the USA undertake intensive actions aiming at the protection of domestic production against competitive import and are not willing to denounce this policy. A factor, which could potentially help revive negotiations towards the free trade agreement between the EU and the USA may relate to the growing pressure of emerging economies, causing on both sides of the Atlantic the need to stimulate economic growth in the long-term perspective. Moreover, the EU may strive to revive negotiations on the bilateral agreement on the liberalization of trade from the USA in order to minimize losses resulting from the growing American protectionism. If the will to conclude this agreement appeared also in the USA, its scope may be narrower and the stipulations less ambitious than it had been initially assumed in the TTIP negotiations. Nevertheless, it seems that such a solution might both make it easier to overcome the resistance of the EU member countries previously reluctant to accept the agreement, as well as gain a consensus in the negotiations.

It may also be assumed that reaching an agreement would not only prevent the crisis in the transatlantic relations, but as a result reduce uncertainty and instability in world trade, as well as provide an opportunity to undertake joint actions against dishonest trade practices adopted by China and Russia. The signed agreement might also be a method to overcome the stalemate in negotiations on the forum of the World Trade Organization (WTO). In this case a serious obstacle in the preparation of a multilateral compromise may be posed by the differences in the position of economically developed and developing countries.

In this discussion concerning modifications of the capacity of the EU agri-food sector to compete on the US market at the conclusion of a preferential trade agreement, only the consequences for the agreement signatories were considered. However, establishment of the transatlantic partnership would lead to the creation of the largest free trade area in the world and would also influence third countries, not being parties to this agreement. For this reason, in the course of further research it would be advisable to investigate consequences of the potential agreement for the agri-food sectors in the other trade partners of the EU and the USA as well as their competitive position both on the transatlantic market and in the world trade.

Funding: This research was funded by the National Science Centre within the OPUS research project No. 2015/17/B/HS4/00262, titled "Polish agri-food sector under the implementation of the Transatlantic Trade and Investment Partnership agreement (TTIP)". The APC was funded by the Faculty of Economics, Poznań University of Life Sciences.

Conflicts of Interest: The author declares no conflict of interest.

\section{References}

1. Wojciechowski, H. Światowy Rynek Żywności. Powstanie—Rozwój-Przemiany (World Food Market. Rise-Development—Changes); Państwowe Wydawnictwo Naukowe: Warsaw, Poland, 1980. (In Polish)

2. UNCTAD Data Center. Available online: https://unctadstat.unctad.org/wds/ReportFolders/reportFolders.aspx (accessed on 31 July 2021).

3. Adamowicz, M. Handel Zagraniczny a Rolnictwo (Foreign Trade and Agriculture); Książka i Wiedza: Warsaw, Poland, 1988. (In Polish)

4. Bonciu, F. Transatlantic economic relations and the prospects of a new partnership. Rom. J. Eur. Aff. 2013, 13, 20-35. [CrossRef]

5. Akhtar, S.I.; Jones, V.C. Transatlantic Trade and Investment Partnership (TTIP) Negotiations; Congressional Research Service Report R43387; Congressional Research Service: Washington, DC, USA, 2014.

6. McKinney, J.A. Transatlantic conflict and cooperation concerning trade issues. Manag. Glob. Transit. 2014, 12, $201-217$. 
7. Wróbel, A. Specyfika liberalizacji handlu rolnego w TTIP (Agricultural Trade Liberalisation and the Logic of the TTIP). In TTIP. Transatlantyckie Partnerstwo w Dziedzinie Handlu i Inwestycji. Nowy Etap Instytucjonalizacji Wspótpracy UE-USA (Transatlantic Trade and Investment Partnership-A New Stage of Institutionalization of the EU-US Cooperation); Dunin-Wasowicz, M., Jarczewska, A., Eds.; Wydawnictwo Naukowe Scholar: Warsaw, Poland, 2015; pp. 214-230. (In Polish)

8. Eliasson, L.J.; Garcia-Duran Huet, P. TTIP negotiations: Interest groups, anti-TTIP civil society campaigns and public opinion. J. Transatl. Stud. 2018, 16, 101-116. [CrossRef]

9. Eken, I. The United States' New Outlook on Transatlantic Partnership (US-European controversy). J. Appl. Bus. Econ. 2020, 22, 62-73. [CrossRef]

10. Pietrzyck, K.; Jarzębowski, S.; Petersen, B. Exploring Sustainable Aspects Regarding the Food Supply Chain, Agri-Food Quality Standards, and Global Trade: An Empirical Study among Experts from the European Union and the United States. Energies 2021, 14, 5987. [CrossRef]

11. Paszewski, T. Perspektywy transatlantyckiej strefy wolnego handlu (Prospects for the transatlantic free trade areas). In Wspótpraca Transatlantycka. Aspekty Polityczne, Ekonomiczne i Społeczne (Transatlantic Cooperation. Its Political, Economic and Social Aspects); Fiszer, J.M., Olszewski, P., Piskorska, B., Podraza, A., Eds.; Instytut Studiów Politycznych Polskiej Akademii Nauk, Fundacja im. Konrada Adenauera: Warsaw, Poland, 2014; pp. 135-151. (In Polish)

12. Francois, J.; Manchin, M.; Norberg, H.; Pindyuk, O.; Tomberger, P. Reducing Trans-Atlantic Barriers to Trade and Investment: An Economic Assessment; Centre for Economic Policy Research (CEPR): London, UK, 2013.

13. European Commission. Trade SIA on the Transatlantic Trade and Investment Partnership (TTIP) between the EU and the USA; Annexes to the Interim Technical Report; European Commission: Brussels, Belgium, 2016.

14. WTI. TTIP and the EU Member States. An Assessment of the Economic Impact of an Ambitious Transatlantic Trade and Investment Partnership at EU Member State Level; World Trade Institute: Bern, Switzerland, 2016.

15. Fontagné, L.; Gourdon, J.; Jean, S. Transatlantic Trade: Whither Partnership, Which Economic Consequences? CEPII Policy Brief, 1; CEPII: Paris, France, 2013.

16. Berden, K.G.; Francois, J.; Tamminen, S.; Thelle, M.; Wymenga, P. Non-Tariff Measures in EU-US Trade and Investment: An Economic Analysis; ECORYS: Rotterdam, The Netherlands, 2009.

17. Rojas-Romagosa, H. Potential economic effects of TTIP for the Netherlands. De Econ. 2017, 165, 271-294. [CrossRef]

18. Honkonen, T. The principle of common but differentiated responsibility in Post-2012 climate negotiations. Rev. Eur. Community Int. Environ. Law 2009, 18, 257-267. [CrossRef]

19. Dunin-Wasowicz, M. Analizy sektorowe państw Unii Europejskiej a TTIP (Sectoral Analyses of TTIP Conducted by the EU Member States). In Analiza Wptywu TTIP na Wybrane Sektory Polskiej Gospodarki (The Impact of TTIP on Selected Sectors of the Polish Economy-An Analysis); Dunin-Wassowicz, M., Ed.; Wydawnictwo Naukowe Scholar: Warsaw, Poland, 2016; pp. 14-53. (In Polish)

20. Bureau, J.-C.; Disdier, A.-C.; Emlinger, C.; Felbermayr, G.; Fontagné, L.; Fouré, J.; Jean, S. Risks and Opportunities for the EU Agri-food Sector in a Possible EU-US Trade Agreement; CEPII Research Report No. 2014-01; CEPII: Paris, France, 2014. Available online: https:/ / www.europarl.europa.eu/RegData/etudes/STUD/2014/514007/AGRI_IPOL_STU(2014)514007_EN.pdf (accessed on 6 May 2021).

21. Poczta-Wajda, A.; Sapa, A. Potential trade effects of tariff liberalization under the Transatlantic Trade and Investment Partnership (TTIP) for the EU agri-food sector. J. Agribus. Rural Dev. 2017, 2, 421-433. [CrossRef]

22. Pawlak, K. Tariff barriers to the EU and the US agri-food trade in the view of the TTIP negotiation. In Agrarian Perspectives XXV. Global and European Challenges for Food Production, Agribusiness and Rural Economy, Proceedings of the 25th International Scientific Conference; Czech University of Life Sciences Prague, Faculty of Economics and Management: Prague, Czech Republic, 2016; pp. 244-250.

23. Pawlak, K. Agricultural support policy as a determinant of international competitiveness: Evidence from the EU and US. In Proceedings of the 2018 International Conference "Economic Science for Rural Development" No 47, Jelgava, Latvia, 9-11 May 2018; Latvia University of Life Sciences and Technologies: Jelgava, Latvia, 2018; pp. 229-237.

24. Pawlak, K.; Poczta, W. Agricultural Resources and their Productivity: A Transatlantic Perspective. Eur. Res. Stud. J. 2020, 23, 18-49. [CrossRef]

25. Pawlak, K.; Smutka, L.; Kotyza, P. Agricultural Potential of the EU Countries: How Far Are They from the USA? Agriculture 2021, 11, 282. [CrossRef]

26. Hagemejer, J.; Michałek, J.J.; Pawlak, K. Ocena wpływu podpisania TTIP na polski sektor rolny i spożywczy (Assessment of TTIP's Effects on the Polish Agricultural and Food Sector). In Analiza Wptywu TTIP na Wybrane Sektory Polskiej Gospodarki (The Impact of TTIP on Selected Sectors of the Polish Economy-An Analysis); Dunin-Wasowicz, M., Ed.; Wydawnictwo Naukowe Scholar: Warsaw, Poland, 2016; pp. 120-197. (In Polish)

27. Serrão, A. A comparison of agricultural productivity among European countries. Mediterr. J. Econ. Agric. Environ. 2003, 2, 14-20.

28. Swinnen, J.F.M.; Vranken, L. Reforms and agricultural productivity in Central and Eastern Europe and the Former Soviet Republics: 1989-2005. J. Product. Anal. 2010, 33, 241-258. [CrossRef]

29. Poczta, W.; Pawlak, K. Potenzielle Wettbewerbsfächigkeit und Konkurrenzposition des polnischen Landwirtschaftssektors auf dem Europäischen Binnenmarkt (Potential competitiveness and competitive position of the Polish agri-food sector on the Single European Market). Ber. Landwirtsch. 2011, 89, 134-169. (In German) 
30. Baer-Nawrocka, A.; Markiewicz, N. Relacje między czynnikami produkcji a efektywność wytwarzania w rolnictwie Unii Europejskiej (Production potential and agricultural effectiveness in European Union countries). J. Agribus. Rural Dev. 2013, 3, 5-16. (In Polish)

31. Pawlak, K. Agricultural productivity, trade and food self-sufficiency: Evidence from Poland, the EU and the US. In Agrarian Perspectives XXVII. Food Safety-Food Security, Proceedings of the 27th International Scientific Conference, Prague, Czech Republic, 19-20 September 2018; Czech University of Life Sciences Prague, Faculty of Economics and Management: Prague, Czech Republic, 2018; pp. 215-221.

32. Baráth, L.; Fertő, I. Productivity and Convergence in European Agriculture. J. Agric. Econ. 2017, 68, 228-248. [CrossRef]

33. Jaroszewska, J.; Rembisz, W. Relacje czynnikowe i produktywnościowe w rolnictwie Unii Europejskiej (Factor and Productivity Relations in EU Agriculture). Wieś Rol. 2019, 2, 31-55. (In Polish) [CrossRef]

34. Kijek, A.; Kijek, T.; Nowak, A.; Skrzypek, A. Productivity and its convergence in agriculture in new and old European Union member states. Agric. Econ. Czech 2019, 65, 1-9. [CrossRef]

35. Bożek, J.; Nowak, C.; Zioło, M. Changes in agrarian structure in the EU during the period 2010-2016 in terms of typological groups of countries. Agric. Econ. Czech 2020, 66, 307-316. [CrossRef]

36. Guth, M.; Smędzik-Ambroży, K. Economic resources versus the efficiency of different types of agricultural production in regions of the European Union. Econ. Res. Ekon. Istraž. 2020, 33, 1036-1051. [CrossRef]

37. Antimiani, A.; Carbone, A.; Costantini, V.; Henke, R. Agri-food exports in the enlarged European Union. Agric. Econ. Czech 2012, 58, 354-366. [CrossRef]

38. Carraresi, L.; Banterle, A. Agri-food Competitive Performance in EU Countries: A Fifteen-Year Retrospective. Int. Food Agribus. Manag. Rev. 2015, 18, 37-62.

39. Bojnec, Š.; Fertő, I. Agri-Food Export Competitiveness in European Union Countries. J. Common Mark. Stud. 2015, 53, 476-492. [CrossRef]

40. Bojnec, Š.; Fertő, I. Are new EU member states catching up with older ones on global agri-food markets? Post-Communist Econ 2015, 27, 205-215. [CrossRef]

41. Bojnec, Š.; Fertő, I. Drivers of the duration of comparative advantage in the European Union's agri-food exports. Agric. Econ. Czech 2018, 64, 51-60. [CrossRef]

42. Bojnec, Š.; Fertő, I. Agri-food comparative advantages in the European Union countries by value chains before and after enlargement towards the East. Agraarteadus J. Agric. Sci. 2019, 30, 69-77. [CrossRef]

43. Juchniewicz, M.; Łukiewska, K. Competitive position of the food industry of the European Union on the global market. Acta Sci. Pol. Oeconomia 2015, 14, 63-72.

44. Pawlak, K. Importance and comparative advantages of the EU and US agri-food sector in world trade in 1995-2015. Zesz. Nauk. Szk. Gł. Gospod. Wiej. Warsz. Probl. Rol. Świat. 2017, 17, 236-248. [CrossRef]

45. Wijnands, J.H.M.; van der Meulen, B.M.J.; Poppe, K.J. Competitiveness of the European Food Industry. An Economic and Legal Assessment 2007; European Commission Project No. 30777; LEI: The Hague, The Netherlands, 2006.

46. Wijnands, J.H.M.; Bremmers, H.J.; van der Meulen, B.M.J.; Poppe, K.J. An economic and legal assessment of the EU food industry's competitiveness. Agribusiness 2008, 24, 417-439. [CrossRef]

47. Wijnands, J.H.M.; Verhoog, D. Competitiveness of the EU Food Industry. Ex-Post Assessment of Trade Performance Embedded in International Economic Theory; LEI Report 2016-018; LEI Wageningen UR (University \& Research Centre): Wageningen, The Netherlands, 2016.

48. Pawlak, K. Stan przemysłu spożywczego w Polsce na tle pozostałych krajów UE i USA (The State of Food Industry in Poland against the Rest of the European Union Countries and the US). Zesz. Nauk. Szk. Gt. Gospod. Wiej. Warsz. Probl. Rol. Swiat. 2016, 16, 313-324. (In Polish)

49. Pawlak, K. Zdolność konkurencyjna przemysłu spożywczego krajów UE, USA i Kanady na rynku światowym (Competitive Capacity of the EU, the US and Canadian Food Industry on the World Market). Zesz. Nauk. Szk. Gt. Gospod. Wiej. Warsz. Probl. Rol. Świat. 2018, 18, 248-261. (In Polish) [CrossRef]

50. Pawlak, K.; Poczta, W. Pozycja konkurencyjna polskiego sektora rolno-spożywczego na Jednolitym Rynku Europejskim (Competitive Position of the Polish Agri-Food Sector on the EU Market). Wieś Rol. 2008, 4, 81-102. (In Polish)

51. Pawlak, K.; Jabkowski, D. Przewagi komparatywne USA w eksporcie wybranych surowców roślinnych na Jednolity Rynek Europejski (Comparative Advantages of the US in the Export of Selected Plant Raw Materials to the Single European Market). Zesz. Nauk. Szk. Gt. Gospod. Wiej. Warsz. Probl. Rol. Świat. 2018, 18, 370-381. (In Polish) [CrossRef]

52. Pawlak, K. Comparative advantages of the Polish agri-food sector on the US market. In Proceedings of the 2018 International Scientific Conference "Economic Sciences for Agribusiness and Rural Economy", Warsaw, Poland, 7-8 June 2018; Warsaw University of Life Sciences-SGGW, Faculty of Economic Sciences: Warsaw, Poland, 2018; pp. 223-230. [CrossRef]

53. Reed, M.R.; Marchant, M.A. The global competitiveness of the U. S. food processing industry. Northeast. J. Agric. Resour. Econ. 1992, 21, 61-70. [CrossRef]

54. Latruffe, L. Competitiveness, Productivity and Efficiency in the Agricultural and Agri-Food Sectors; OECD Food, Agriculture and Fisheries Working Papers No. 30; OECD Publishing: Paris, France, 2010.

55. Siggel, E. International competitiveness and comparative advantage: A survey and a proposal for measurement. J. Ind. Compet. Trade 2006, 6, 137-159. [CrossRef] 
56. Frohberg, K.; Hartmann, M. Comparing Measures of Competitiveness; Discussion Paper No. 2; Institute of Agricultural Development in Central and Eastern Europe (IAMO): Halle (Saale), Germany, 2000.

57. Balassa, B. Trade Liberalisation and "Revealed" Comparative Advantage. Manch. Sch. 1965, 33, 99-123. [CrossRef]

58. Anderson, K. China's Economic Growth, Changing Comparative Advantages and Agricultural Trade. Rev. Mark. Agric. Econ. 1990, 58, 56-75. [CrossRef]

59. Abbas, S.; Waheed, A. Trade competitiveness of Pakistan: Evidence from the revealed comparative advantage approach. Compet. Rev. Int. Bus. J. 2017, 27, 462-475. [CrossRef]

60. Szczepaniak, I. Comparative advantages in Polish export to the European Union-food products vs selected groups of non-food products. Oeconomia Copernic. 2018, 9, 287-308. [CrossRef]

61. Vollrath, T.L. Competitiveness and Protection in World Agriculture; Agriculture Information Bulletin No. 56; U.S. Department of Agriculture, Economic Research Service: Washington, DC, USA, 1989.

62. Szczepaniak, I. Changes in comparative advantages of the Polish food sector in world trade. Equilib. Q. J. Econ. Econ. Policy 2019, 14, 463-480. [CrossRef]

63. Erokhin, V.; Diao, L.; Du, P. Sustainability-Related Implications of Competitive Advantages in Agricultural Value Chains: Evidence from Central Asia-China Trade and Investment. Sustainability 2020, 12, 1117. [CrossRef]

64. Bojnec, Š. Trade and Revealed Comparative Advantage Measures: Regional and Central and East European Agricultural Trade. East. Eur. Econ. 2001, 39, 72-98. [CrossRef]

65. Rytko, A. Środkowoeuropejskie Porozumienie Wolnego Handlu CEFTA jako Studium Rozwoju Integracji Europejskiej w Sferze Rolnictwa $i$ Gospodarki Żywnościowej (Central European Free Trade Agreement (CEFTA) as a Study of the Development of European Integration in the Field of Agriculture and Food Economy); Wydawnictwo SGGW: Warsaw, Poland, 2003. (In Polish)

66. Hambalková, M. The factors of competitiveness and the quantification of their impact on the export efficiency of grape and wine in the Slovak Republic. Agric. Econ. Czech 2006, 52, 389-394. [CrossRef]

67. Cimpoies, L. An analysis of Moldova's agri-food products competitiveness on the EU market. Agric. Agric. Sci. Procedia 2016, 10, 532-538. [CrossRef]

68. Kita, K. Międzynarodowa pozycja konkurencyjna polskich artykułów rolno-spożywczych na rynnach wybranych krajów azjatyckich—stan i perspektywy (The International Competitive Position of Polish Agri-Food Products on the Selected Asian Markets-Current Status and Prospects). Zesz. Nauk. Szk. Gt. Gospod. Wiej. Warsz. Probl. Rol. Świat. 2016, 16, 153-166. (In Polish)

69. Babu, S.C.; Shishodia, M. Analytical Review of African Agribusiness Competitiveness. Afr. J. Manag. 2017, 3, 145-162. [CrossRef]

70. Posłuszny, K. Konkurencyjność międzynarodowa jako miara skuteczności restrukturyzacji przemysłu (International competitiveness as a measure of industry restructuring effectiveness). Ekon. Menedż. 2011, 9, 49-61. (In Polish)

71. Laursen, K. Revealed comparative advantage and the alternatives as measures of international specialization. Eurasian Bus. Rev. 2015, 5, 99-115. [CrossRef]

72. Laursen, K. Revealed Comparative Advantage and the Alternatives as Measures of International Specialisation; DRUID Working Paper No. 98-30; Danish Research Unit for Industrial Dynamics, Copenhagen Business School, Department of Industrial Economics and Strategy: Copenhagen, Denmark, 1998.

73. Dalum, B.; Laursen, K.; Villumsen, G. Structural Change in OECD Export Specialisation Patterns: De-specialisation and 'stickiness'. Int. Rev. Appl. Econ. 1998, 12, 423-443. [CrossRef]

74. Widodo, T. Comparative Advantage: Theory, Empirical Measures and Case Studies. Rev. Econ. Bus. Stud. 2009, 4, 57-82.

75. Ishchukova, N.; Smutka, L. "Revealed" Comparative Advantage: Products Mapping of the Russian Agricultural Exports in Relation to Individual Regions. Acta Sci. Pol. Oeconomia 2014, 13, 45-61.

76. Smutka, L.; Maitah, M.; Svatoš, M. Changes in the Czech agrarian foreign trade competitiveness-different groups of partners' specifics. Agric. Econ. Czech 2018, 64, 399-411. [CrossRef]

77. Verter, N.; Zdráhal, I.; Bečvářová, V.; Grega, L. 'Products mapping' and trade in agri-food products between Nigeria and the EU28. Agric. Econ. Czech 2020, 66, 34-45. [CrossRef]

78. Zdráhal, I.; Verter, N.; Lategan, F. 'Products Mapping' of South Africa's Agri-food trade with the EU28 and Africa. AGRIS Online Pap. Econ. Inform. 2020, 12, 133-149. [CrossRef]

79. Comext-Eurostat. International Trade Data. Available online: http://epp.eurostat.ec.europa.eu/newxtweb/ (accessed on 5 August 2021)

80. Yurik, S.; Pushkin, N.; Yurik, V.; Halík, J.; Smutka, L. Analysis of Czech agricultural exports to Russia using mirror statistics. Entrep. Bus. Econ. Rev. 2020, 8, 27-46. [CrossRef]

81. Lafay, G. The Measurement of Revealed Comparative Advantages. In International Trade Modeling; Dagenais, M.G., Muet, P.A., Eds.; Chapman \& Hill: London, UK, 1992; pp. 209-234.

82. Pawlak, K.; Poczta, W. Handel wewnątrzgałęziowy w wymianie produktami rolno-spożywczymi UE z USA (Intra-industry Trade in Agri-food Products between the EU and US). Zesz. Nauk. Szk. Gt. Gospod. Wiej. Warsz. Probl. Rol. Świat. 2019, 19, 93-102. (In Polish) [CrossRef]

83. Salvacruz, J.; Reed, M. Identifying the best market prospects for US agricultural exports. Agribusiness 1993, 9, 29-41. [CrossRef]

84. Loertscher, R.; Wolter, F. Determinants of intra-industry trade: Among countries and across industries. Rev. World Econ. Weltwirtsch. Arch. 1980, 116, 280-293. [CrossRef] 
85. Jámbor, A. Country- and industry-specific determinants of intra-industry trade in agri-food products in the Visegrad countries. Stud. Agric. Econ. 2015, 117, 93-101. [CrossRef]

86. Łapińska, J. Determinant factors of intra-industry trade: The case of Poland and its European Union trading partners. Equilib. Q. J. Econ. Econ. Policy 2016, 11, 251-264. [CrossRef]

87. Bojnec, Š.; Fertő, I. Patterns and drivers of the agri-food intra-industry trade of European Union countries. Int. Food Agribus. Manag. Rev. 2016, 19, 53-74.

88. WITS-TRAINS. Available online: https:/ / wits.worldbank.org/default.aspx (accessed on 17 May 2021).

89. Thompson-Lipponen, C.; Greenville, J. The Evolution of the Treatment of Agriculture in Preferential Trade Agreements; OECD Food, Agriculture and Fisheries Papers No. 126; OECD Publishing: Paris, France, 2019.

90. Raimondi, V.; Falco, C.; Curzi, D.; Olper, A. Trade effects of geographical indication policy: The EU case. J. Agric. Econ. 2020, 71, 330-356. [CrossRef]

91. Kuźnar, A. TTIP a interesy Unii Europejskiej i Stanów Zjednoczonych w zakresie własności intelektualnej (TTIP and the interests of the European Union and the United States in the field of intellectual property). In Partnerstwo Transatlantyckie. Wnioski dla Polski (Transatlantic Partnership. Conclusions for Poland); Czarny, E., Słok-Wódkowska, M., Eds.; Polskie Wydawnictwo Ekonomiczne: Warsaw, Poland, 2016; pp. 83-100. (In Polish)

92. Matthews, A. What outcome to expect on geographical indications in the TTIP free trade negotiations with the United States? In Intellectual Property Rights for Geographical Indications: What Is at Stake in the TTIP? Arfini, F., Mancini, M., Veneziani, M., Donati, M., Eds.; Cambridge Scholars Publishing: Newcastle, UK, 2016; pp. 2-18.

93. WTO. Integrated Trade Intelligence Portal (I-TIP). Available online: http:/ / i-tip.wto.org/goods/Forms/TableView.aspx (accessed on 13 August 2021). 